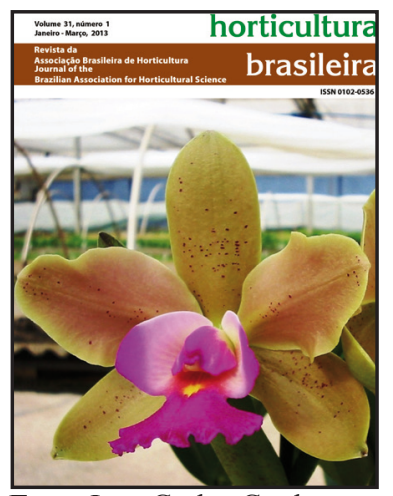

Foto: Jean Carlos Cardoso

\section{Melhoramento de espécies ornamentais como estratégia para o desenvolvimento e autossuficiência do setor}

Desde 2008, quando o Brasil atingiu seu auge na exportação de produtos da floricultura (US\$ 35,6 milhões), o país vem acumulando reduções gradativas nas exportações (US\$ 26,1 milhões em 2012). Este fato, associado ao valor recorde de importações em 2012 (US\$ 40,1 milhões), resultou em redução drástica na balança comercial brasileira nessa classe de produtos, acumulando um déficit nunca visto antes de US\$ 14 milhões em 2012 (http://aliceweb2. mdic.gov.br//index/home).

Os resultados negativos obtidos no setor devem-se em grande parte à confiança e à garantia que os produtores têm nas cultivares desenvolvidas no exterior, em especial, aquelas provenientes de grandes empresas multinacionais, chamadas de Breeders, sediadas em países como a Holanda, EUA e outros do continente Asiático. Prova disso é o aumento nas importações de mudas (orquídeas e outras), cujo valor passou de U\$ 7,3 milhões em 2010 para U\$ 13,0 milhões em 2012, deixando um déficit na balança comercial neste segmento específico no último ano de US\$ 4,1 milhões. Nesse contexto, o maior causador do déficit tem sido, curiosamente, o aumento das importações de mudas de orquídeas (US\$ 8,8 milhões) (http://aliceweb2.mdic.gov. br//index/home). Contribuiu também para esta realidade deficitária no comércio internacional, o crescimento e maior facilidade de comercialização de produtos da floricultura no mercado interno, que, aumentando seu consumo, causa uma redução inevitável nas exportações. Outro aspecto a ser considerado, é o pagamento compulsório de royalties aos Breeders pelo uso de cultivares protegidas (http://www. sober.org.br), o que não só onera os custos de produção, mas também leva à diminuição do valor monetário que permanece no país referente à produção de flores.

O desenvolvimento de cultivares superiores é sabidamente demorado e oneroso, portanto com altos custos de produção. Por isso, é importante que os royalties sejam recolhidos, como justa remuneração pelos serviços e investimentos feitos no desenvolvimento de cultivares de maior valor tecnológico e comercial, exploradas por toda a cadeia da floricultura no mundo.

Levando em consideração este aspecto e tendo em perspectiva a grande diversidade genética de espécies com fins ornamentais que são nativas do Brasil, uma estratégia para alavancar o setor nacional e torná-lo autossuficiente, é o estabelecimento de programas brasileiros de melhoramento genético de flores e plantas ornamentais. Para isso, é necessário que sejam feitos maiores investimentos em prospecção e biologia reprodutiva das principais espécies cultivadas no país, de modo a desenvolver cultivares com padrão de excelência similar e até mesmo superior ao das cultivares estrangeiras.

Há programas de melhoramento genético para algumas espécies nativas e também exóticas, com destaque para o Instituto Agronômico de
Campinas (IAC), no desenvolvimento de cultivares de antúrios de corte, e Universidade Estadual de Londrina, no desenvolvimento de cultivares de Dendrobium nobile. Atualmente, algumas empresas particulares de produção de flores também têm realizado ações de melhoramento, como, por exemplo, o desenvolvimento de cultivares e híbridos de orquídeas nativas e exóticas para o mercado de flores de vaso, a exemplo do híbrido que ilustra nossa capa.

Um ponto crítico dos programas de melhoramento genético de flores em todo o mundo é o foco quase que exclusivo em características ornamentais, com as características agronômicas colocadas em segundo plano. Isso contribui para o aumento dos custos de produção dessas novas cultivares, que em geral são mais suscetíveis à incidência de pragas e doenças, têm crescimento lento e, em algumas espécies, longo período juvenil.

Soma-se a isso o fato de que a maioria dos programas de melhoramento de espécies ornamentais é conduzido utilizando técnicas tradicionais, como, por exemplo, cruzamentos controlados. Ferramentas biotecnológicas aplicadas ao melhoramento genético, que poderiam reduzir o tempo necessário para desenvolver uma nova cultivar, ampliar as possibilidades de uso efetivo da variabilidade genética e aumentar a eficiência na fase de seleção, têm sido pouco exploradas em espécies ornamentais. Entretanto, é muito importante que essas ferramentas sejam integradas ao melhoramento convencional como próximo passo no desenvolvimento de cultivares de flores no Brasil.

É importante mencionar ainda o marco regulatório. Nesse sentido, embora alguns avanços tenham sido obtidos com a Lei de Proteção de Cul- tivares, relativamente atual no Brasil, ainda nos falta uma legislação mais abrangente, que proteja cultivares de flores de diferentes espécies ornamentais, incluindo as nativas. No estágio em que estamos, não há estímulo para que empresas públicas ou privadas entrem no negócio, pela impossibilidade de exercerem controle sobre o uso das cultivares obtidas. Lembremos que nesse setor exclusividade é um fator de garantia de preços e de comercialização do produto final.

Em conclusão, o aumento no número de programas brasileiros de melhoramento genético de espécies ornamentais, bem como o avanço das técnicas utilizadas com essa finalidade, é uma estratégia prioritária para o desenvolvimento de todo o setor. Temos potencial para obter excelentes cultivares e, com elas, passarmos de meros usuários para geradores de tecnologias para a floricultura mundial, com vistas também a atingirmos a autossuficiência na produção de cultivares e mudas. É importante ressaltar que essa linha de raciocínio tem como fundamentos o aumento na competitividade e na geração de novas opções de cultivares para o mercado de flores e não a restrição da entrada de mudas de cultivares importadas no país. A escolha final da cultivar e muda a ser utilizada deve ser sempre do produtor, realizada de acordo com os interesses de atacadistas, varejistas e do consumidor final.

Jean Carlos Cardoso (UFSCar-CCA, Depto. de Desenvolvimento Rural, jeancardoso@cca.ufscar.br)

As idéias aqui expressas refletem a opinião do autor e não da Comissão Editorial. As informações aqui apresentadas são, igualmente, responsabilidade do autor. 